\title{
WAYS OF CHOIRMASTER ART DEVELOPMENT IN AZERBAIJAN
}

\author{
Leila Zaliieva
}

Doctoral Student; ORCID: 0000-0001-8835-2008; e-mail: leyla_zaliyeva@mail.ru

Baku Music Academy named after U. Hajibeyli, Baku, Azerbaijan

\section{Abstract}

The article is devoted to the history of the choral music development in Azerbaijan and to highlighting the ways of choirmaster art formation. The development of choral art in Azerbaijan began, firstly, with the formation of the composer creative activity. The introduction of classical choral samples with the emergence of the first opera and the formation of an ensemble for performing it are considered to be the first step in this area. Later, the emergence of professional choral collectives, the development of the opera genre, as well as the activity of music education institutions included a new stage of development. Therefore, the formation of choral music genres allowed the development of the art of conducting, especially the areas such as an opera choirmaster who leads a choir collective, a chapel choirmaster.

The purpose of the research is to highlight the formation of choral conducting in Azerbaijan, to study the ways of high-level development of choirmaster art and to explore the creative path of professional opera choirmasters.

The research methodology is based on historical and theoretical principles, with the help of which the position of choral art in the musical culture of Azerbaijan, the history of the formation of choral art is considered. The theoretical and methodological basis of the study was the existing works of Russian and Azerbaijani musicologists in this field.

The scientific novelty of the research is connected with the fact that for the first time in Azerbaijan the ways of development of choir art are comprehensively covered.

Conclusions. The involvement of Azerbaijani choral art in the research and the study of the issue mainly in terms of the conducting and choirmaster art formation have shown that the development of this art was primarily connected with composer creativity. Since the emergence of classical samples of choral music is associated with the opera genre, the art of conducting and choirmaster has entered its stage of formation, in parallel. The professional development of choirmaster art took place in parallel and mutually with the art of conducting and it was associated with the high-level organization of music education in the country. Consequently, such professional choirmasters as L. V. Frolova, A. A. Yurlov, N. Malikov, L. Atakishiyeva, E. B. Novruzov, B. Vakilova, S. Agayeva, N. Mardanov, N. Nabiyev, Z. Ismayilova, Y. Adigozalov, G. Imanova and L. Mammadova have been trained in Azerbaijan. Besides, areas such as a chapel and opera choirmaster have also developed within choirmaster art.

Keywords: Azerbaijani musical culture; conductor; choirmaster; national opera art; collective 


\section{Introduction}

The art of conducting is one of the interesting and relatively less studied fields of the science of musicology. According to Rimsky-Korsakov, although the history of this so-called "dark" art is not as old as performing, it is a more difficult issue to determine the main boundaries and criteria of professionalism that express its essence. This is primarily due to the fact that the art of conducting covers many fields combining performing, pedagogical and managerial qualities. Simultaneously, the term conductor refers to a person who leads, as an artistic music director, various creative collectives such as orchestra, ensemble, choir, opera. As it is known, the work mode, repertoire, creativity field, performing style and many distinctive features of each of these groups require a conductor to possess extensive and deep knowledge and skills, talent, high professionalism and aesthetic taste, comprehensive work experience and many other qualities. "The art of conducting is a field requiring comprehensive skills. Among them, there are skills that can be called conducting talent. They consist of the ability to show the content of a piece through gestures, to describe the development of musical material and to have a direct impact on the performers" (Musin, 2006, p. 6).

The formation and development of choirmaster art which is one of the main directions of conducting is closely linked with choral music, one of the richest and unique creative fields of music art. Formed in the first half of the twentieth century, the Azerbaijani choral art having conquered the highest creative peaks during a century as a brilliant carrier of professional criteria has presented valuable pearls of art to the music art. Additionally, professional pedagogues and choirmasters directly engaged in the education, promotion and development of choral art in the country have been working much not only on leading various groups but also on educating the younger generation. "Conducting as an art is multifunctional and represents a complex that combines the fields of interpretation (analysis), performing (heuristics), management (realizing), training (pedagogics) and organization (planning)" (Yerzhemsky, 1988, p. 8).

Choral art has been studied mainly in the context of performing and composer creativity in the science of musicology, valuable scientific researches have emerged that shed light on various aspects. However, the transformation of conducting and particularly choirmaster art into an object of the research has not been observed in scientific researches about choral art. As one of the interesting fields with rich creative and pedagogical professional criteria, choirmaster art has been formed in connection with the activity of choir collectives and the formation of opera in the country. Back in 1908, the great composer U. Hajibeyli achieved aroused interest in this type of music by creating the first four-voice choir sample in the opera "Leyli and Majnun", he also showed the importance of steps to promote the independent development of choral art. The need for conducting along with opera as well as choirmaster art began to be gradually eliminated. Therefore, the interesting and high-quality creative activity of professional conductors-choirmasters representing choral art in Azerbaijan has proved itself on the concert and opera stage, as well as in pedagogical success. From this point of view, the study of choirmaster art and the discovery of its artistic and 
methodological bases cause interest in the science of musicology. The lack of extensive and independent coverage of this topic, the lack of direct analysis and research of choirmaster art makes the research question relevant.

One of the indicators of the relevance of the topic is directly related to the artis tic content of choral art. As it is obvious, the choir as an embodiment of collective performing has such qualities as unity, equality, strength, power and mainly acts as a carrier of the image of the people. The music scenes in the composer creativity expressing the people, representing the idea of struggle, courage, strength and unity are linked with choral episodes. This emphasizes the historical and social, social and psychological function of choral music. The modern content of choral art, its public position are very important in terms of national unity and equality, the struggle against the enemy, the strengthening of patriotic spirit. It shows the interest in choral art for the younger generation and the importance of its educational significance aimed at spiritual enrichment. The promotion, teaching and research of choral art should be the focus of modern music art and scientific research plays an important role in the measures taken to increase the interest of performers, composers and audiences in this art. In this regard, the topic of the article is relevant. At the same time, this topic becomes an interesting and important research object for the pedagogical teaching process of choral art. The pedagogical, methodological and theoretical significance of such research in the training of young choirmasters is undeniable. This is one of the factors determining the relevance of the topic.

\section{Purpose of the research}

The article aims to highlight the formation of choral conducting in Azerbaijan and to study the ways of high-level development of choirmaster art, to have a look at the creative path of professional opera choirmasters.

\section{Recent research and publications analysis}

The importance of choral art and its development on a national basis in the early twentieth century made the great composer U. Hajibeyli and his colleagues think. U. Hajibeyli, who made a great contribution to the formation of both performing and pedagogical resources of this art, noted in his articles and reports about the high artistic content of choral music and the role of choral performing in the development of professional musical art. The important steps taken by the composer in this direction were then successfully continued and resulted in the acquisition of high professional standards by choral art on the national level.

Although the interest in choral music was more active in the art of composition and performing arts, its study from a scientific perspective took place later. This idea is more relevant to scientific research covering the historical, theoretical and pedagogical issues of choral art. Leyla Mammadova-Farajova's monograph on the history of choral art is especially valuable among such studies. In this monograph, the scientist takes a broad look at the stages of the historical formation of choral art in Azerbaijan, sheds light on the main directions of its development. The monograph 
clarifies such issues as the connection of choral art with folk music genres, the role of the U. Hajibeyli phenomenon in the development of this art, the gradual creation of professional teaching stages of the choir class, etc.

The monograph shedding light on the life and creative path of well-known representatives of conducting and choirmaster art in Azerbaijan was written by the musicologist, researcher Gularakhanim Akhundova. This monograph provides extensive information about conductors and choirmasters who worked in Azerbaijan. The study of Azerbaijani choral art has been included in both special and scientific monographs dedicated to the composer creativity. Not only composing but also creative work of M. Magomayev, A. Badalbeyli, Niyazi, S. Alasgarov, T. Guliyev and other artists who acted as conductors is of special importance in this field.

\section{Main research material}

The historical roots of the art of conducting are associated with the formation of collective performing. The formation of the art of conducting in a professional sense is linked with the development of orchestral and choral music during the Renaissance. Composers have made a great contribution to the development of the art of conducting. In the history of music, the names of a number of composers behind the conductor's stand are known to history. However, a new stage in this art is associated with R. Wagner. Prior to Wagner, conductors were turned back to the orchestra and facing the audience. For the first time, Wagner turned to face an orchestra, thus bringing innovation to the art of conducting.

Conducting was one of the fields of art formed in the first half of the twentieth century. The art of conducting first began to take shape with leading opera orchestras. U. Hajibeyli conducted the first mugham operas himself and M. Magomayev helped him in this work. The main field which had great importance for the formation of the art of conducting was choral music. The scientist L. Mammadova, who studies the history of choral art development by stages in Azerbaijan, searches the roots of national choral performing in the older, forgotten layers of folk music in her work "Choral Culture of Azerbaijan": The culture of choral performing, currently quite developed and widespread in the republic, takes its roots from the forgotten ancient folk music samples performed collectively, these performing traditions have been accumulated in the memory of the people for centuries and reflected in the national musical thinking (Mamedova, 2010, p. 13). Later, expanding this idea, the scientist showed that the oldest genre of folk music "Yalli" was the first example of collective performing.

Finding the way to concert stages for Azerbaijani folk music and the adaptation of performances presented here to these criteria became an integral part of the national music culture as a characteristic feature of the time. Besides, the performances of music groups visiting the capital during concert tours, concerts of the symphony orchestra, classical European musical tradition gradually gave an impetus to the formation of the people's musical aesthetic taste in a new direction. "Already in the early twentieth century, more and more famous musicians, opera theatres were having tours, the stream of professional musicians to Baku was growing. In 1895, the activity of the Artists' Society became significantly more active" (Mamedova, 2010, p. 100). 
We can conclude from the described picture and the referred source that choral art in Azerbaijan was first formed in the direction of performing and mainly representatives of other nations were working on its teaching and conducting art to choir groups. This was primarily due to the absence of music education institutions in the country.

It is necessary to mention that along with choral performing, the development of the conducting art was mainly related to the activities of symphony and opera orchestras. This, of course, was linked with the emergence of opera as the first classical genre in national art. There are known facts that Hajibeyli conducted mugham operas and musical comedies himself. M. Magomayev also played an important role in this work. "Muslim Magomayev's conducting activity began in 1911 and he was mentioned in the scientific literature as the first Azerbaijani conductor. Later Afrasiyab Badalbeyli, Niyazi, Ashraf Hasanov, Ahad Israfilzade, Chingiz Hajibeyov, Kazim Aliverdibeyov, Rauf Abdullayev, Fakhraddin Karimov, Javanshir Jafarov, Eyyub Guliyev, Yalchin Adigozalov and other opera-symphonic conductors continued this field (Hasanova \& Mahmudova, 2017, p. 48). The experience of composers in the field of conducting in the following period gives grounds to say that composers played a great role in the formation of the conducting art in Azerbaijan as a professional activity. In the history of national music, U. Hajibeyli, M. Magomayev, A. Badalbeyli, S. Alasgarov, H. Khanmammadov, T. Guliyev, S. Hajibeyov, J. Jahangirov, S. Rustamov, T. Guliyev, R. Mustafayev played a unique role in the development of the conducting art. A. Badalbeyli and T. Guliyev among these composers received professional education in conducting. Other composers worked as conductors in professional collectives of the republic in different years. J. Jahangirov and R. Mustafayev's services as choirmasters are irreplaceable in the professional development of this art. "After graduating from the conservatory, R. Mustafayev first worked in the choir of the Azerbaijan Radio Committee as an assistant conductor to J. Jahangirov and from 1958, he worked as an artistic director and chief conductor in the choir of radio and television. The work with the choir was also reflected in the composer activity. Therefore, he created a large number of choral works, cantatas and oratorios, arrangements of folk songs (Qafarova, 2009, p. 20). As it can be seen, Azerbaijani composer services in the development of choral and orchestral music are of wide and comprehensive importance.

In addition to all this, in the 1940s and 1950s, the professional embodiment of the art of conducting in Azerbaijan entered the history of music with the name of a prominent musician, conductor, composer Niyazi. Though he did not have direct education in conducting, the talented musician's creativity played a fundamental role in the formation of professional criteria of this art and possessing its peculiar traditions in the national art.

Despite his young age, Niyazi had already worked as an art director in the prestigious orchestras of the former Soviet Union in the 1950s and he was the first interpreter of Azerbaijani composers' works. "Niyazi's conducting activity was extensive and multifaceted. He applied to the creativity of Russian and foreign composers including Beethoven, Mozart, Wagner, Dvorjak, Rachmaninoff, Tchaikovsky, Rimsky-Korsakov, Prokofiev, Shostakovich and others. He was the first interpreter of the outstanding works by Uzeyir Hajibeyli, Muslim Magomayev, Gara Garayev, Fikret Amirov, Arif Malikov and other composers (Akhundova, 2016, p. 99). 
The special role of the prominent composer, conductor, musicologist, public figure Afrasiyab Badalbeyli at the initial stage of development of the art of conducting in Azerbaijan should also be noted. As early as 1932, the composer acquired professional knowledge of conducting at the Moscow Conservatory and later devoted a large part of his life to this art. A. Badalbeyli, who worked for many years as a conductor and chief conductor at the Azerbaijan State Opera and Ballet Theatre named after M. F. Akhundov, was closely acquainted with the secrets of this art and made a special contribution to the creation of the high position of the art of conducting in national culture and to the formation of professional criteria.

In 1951, the Department of Choir Conducting was established at the Azerbaijan State Conservatory. Another direction of the art of conducting in Azerbaijan entered the path of professional development with the opening of this department. The main target of this department was to train educated and professional choirmasters in the country. L. V. Frolova, composers J. Jahangirov V. Adigozalov and M. Mirzayev, choir specialists such as A. A. Yurlov, N. Malikov, L. Atakishiyeva, E. B. Novruzov, B. Vakilova, S. Agayeva, N. Mardanov, N. Nabiyev, Z. Ismayilova, Y. Adigozalov, G. Imanova, L. Mammadova working here have made a great contribution to the training of conductors and choirmasters who have conquered the highest peaks of this art. As a result of the successful activity of the Department of Choir Conducting, this field of the art of conducting plays an important role in the training of educated specialists.

Thus, if we look at the general historical picture, it seems that the art of conducting in Azerbaijan has been gradually formed. Its first stage started with opera conducting. The next stage is associated with a symphony orchestra and choir conducting. In addition to these fields, the conducting of various ensembles and orchestras of folk instruments also began to take shape.

As we noted earlier, although the emergence of choir collectives in Azerbaijan gave an impetus to the development of performing arts, the training of local specialists took place a little later. To be more precise, this process began only with the opening of the "Choir Conducting" department at the Azerbaijan State Conservatory.

L. V. Frolova, who started working at the "Choir Conducting" department in 1951, also headed this department. She received professional education in this speciality at the Moscow State Conservatory, had successful concert activity with various choir collectives. When this department was opened in Azerbaijan, Gara Garayev invited L. Frolova to head this department. The successful activity of the Choir Conducting Department from the first years of its opening was characterized by the fact that its first graduates became leading specialists in the national choirmaster art. Among them, there were such names as N. Malikov, L. Atakishiyeva, R. Afendiyev, K. Abbasov.

The development of choirmaster art was also associated with the work of specialists studying this field in the opera theatre. It is necessary to emphasize the importance of the time and location factors of the creative process as a key feature of the principle of working with a cappella team and the choir collective of the opera theatre. It is these factors in front of the choirmaster that determine the main directions for establishing the principle of work. Since the artistic and aesthetic requirements to these groups have different aspects, the principle of working with them, the solution of the repertoire problem is organized according to different criteria. During the activity of 
the department of "Choir Conducting," both directions of choirmaster art have undergone a process of development, professional specialists working in the opera theatre, with a cappella and other choir groups, as well as engaged in pedagogical activities have been trained.

Nijat Malikov is one of the choirmasters conductors who led choirmaster activities in the opera theatre and achieved successful creative achievements. His activity both in the Opera and Ballet Theatre and in the "Choir Conducting" department of the conservatory played an important role in the formation and development of choirmaster art in Azerbaijan. The talented musician, who started practising this art in his student years, not only become acquainted with the secrets of art but also made great contributions to its development and acquiring professional criteria. N. Malikov acted as a choirmaster of operas such as "Carmen", "Rusalka (Mermaid)", "Iolanta", "Boris Godunov", "The Queen of Spades”, "Knyaz Igor (Prince Igor)” and others. After staging numerous opera performances in 1958, N. Malikov was appointed chief choirmaster of the theatre and worked there until the last days of his life. His friends and colleagues noted that N. Malikov was distinguished by a sensitive approach to musical material, high professionalism, a good sense of music, seriousness, exactingness to himself and choir artists, as well as his students (Akhundova, 2016, p. 29).

Honoured Art Worker Bibietta Vakilova was one of the people who worked with N. Malikov and she was full of wonderful impressions about him. B. Vakilova's personal creative way, who devoted her whole life with her opera choirmaster and pedagogical activity to the development of this art, is noteworthy. Deeply aware of the secrets of choirmaster art, B. Vakilova's creative path is very rich and comprehensive. Having gained great pedagogical experience working in various music educational institutions of the republic, the talented choirmaster demonstrated her high professionalism and conducting skills on the stage of the Azerbaijan State Opera and Ballet Theatre. B. Vakilova, who worked with this collective for many years, showed her attention and sensitive attitude to art and its carriers as a choirmaster and it was manifested during the work on musical works too. "A peculiar interpretation of U. Hajibeyli's operetta "Arshin mal alan" prepared at the Opera Studio brought her the first prize in 1987 at the festival of young theatres in Moscow" (Abdulzade, 2015, p. 47).

The main noteworthy point in the work style of the experienced musician is the acquisition of high professional performing skills, regardless of the level of training of the choir collective. If the staff of the Opera and Ballet Theatre was composed of educated musicians, it was impossible to say the same about the choir group of the Opera and Ballet Theatre in Antalya, Turkey. B. Vakilova managed to instil in musicians high professional performing skills during the short time of working with this ensemble. "When I was working there, many musicians had poor note literacy. I pay attention first to the clear sound of the interval. Traditionally, after the work on the individual parties is over, the main issue begins with the work on the ensemble. Here the division is based on male and female voices. For me, in addition to other details, it is more important to work first on the image. I prefer expressive and figurative presentation during the performance" (From private conversations).

Laman Atakishiyeva's name, who had services in the development of Azerbaijani choral art and who was one of the talented conductors working on the forma- 
tion of professional criteria for choirmaster art, is an important page in the history of culture.

Having mastered the secrets of this art in the class of a professional pedagogue and talented choirmaster L. Frolova, L. Atakishiyeva is one of the artists who later dedicated her whole life to its development. The period of her education coincided with the years of work of the prominent conductor-choirmaster A. Yurlov who gave a great impetus to the development of choral art in Azerbaijan and defined its main directions. A. A. Yurlov, a very talented musician, choirmaster and promoter of choral music, who was invited to Baku in 1954, played a key role in the formation of Laman Atakishiyeva's creative personality as a choirmaster. Although A. Yurlov worked in Baku for a very short time (until 1956), his active pedagogical, creative and organizational activities gave an impetus to the revival of the choral art performing in Azerbaijan (Akhundova, 2016, p. 44).

L. Atakishiyeva's musical sense and deep mastery of the secrets of choral performing were enough to successfully cope with this task. Thanks to this hard work and talent, she was awarded the first prize at the Festival of Transcaucasian Amateur Groups (Mamedova (Farajeva), 2013). L. Atakishiyeva's talent and rich experience were also highly appreciated far from home. It is no coincidence that Laman's bright talent, professional choirmaster activity, who was invited to work at the Opera and Ballet Theatre in Istanbul, Turkey in 1981, was remembered with great sympathy in the music culture of this group and the country for many years. Moreover, Laman Atakishiyeva's hard work and professional style in the preparation of the vocalsymphonic work "Epic" by the famous Turkish composer Adnan Saygun brought attention both to the composer and the music community. In addition, L. Atakishiyeva prepared operas by Russian and European composers performed by this collective, which were met with applause by the Turkish audience.

People's Artist Javanshir Jafarov is one of the talented musicians who worked as a conductor and choirmaster of numerous performances at the Azerbaijan State Opera and Ballet Theatre, who made a great contribution to the development of this art. Having received professional training in conducting and choirmaster specialities, J. Jafarov connected his creative activity with Azerbaijan State Opera and Ballet Theatre from 1979. One of the brightest aspects of his work was his performance both as a symphony orchestra conductor and a choir conductor. To exemplify, he performed excerpts from U. Hajibeyli's opera "Koroglu" as a conductor of a symphony orchestra in 1983 and then continued his activities in both directions.

Under J. Jafarov's leadership, the works by Azerbaijani, Russian and European composers were successfully staged here. Among them, there were U. Hajibeyli's operas "Koroglu”, "Leyli and Majnun”, operettas "Arshin mal alan”, "O olmasin bu olsun”, F. Amirov's ballet "1001 Nights", A. Badalbeyli's ballet "Maiden Tower", A. Alizade's ballets "Babek”, "Journey to the Caucasus", G. Garayev's “Don Quixote”, "Lightning Roads" ballets, J. Verdi's "Traviata", "Troubadour", "Rigoletto", "Aida" operas, R. LeonkovalIo's "Pagliacci”, Puccini's "Madame Butterfly", "La Bohema”, "Manon Lescaut” operas, Rossini's "Barber of Seville" opera, Tchaikovsky's "Nutcracker" ballet and other works.

It is also noteworthy to mention talented choirmaster Sevil Hajiyeva's creativity who successfully continues achievements of modern Azerbaijani choral art and 
has connected her life with the opera and ballet theatre. It is known that the creative activity of the opera and ballet theatre in recent years, especially the fact that choir collectives have faced various social problems, has had a negative impact on the development of this art. Maintaining the collective's high level of creative determination, interest in music and art under these conditions, working to ensure that the criteria of professionalism do not lose their value requires great effort, will and endurance from the choirmaster. These features are typical for the work of talented musician and experienced choirmaster Sevil Hajiyeva.

As a consequence of S. Hajiyeva's hard work and efforts, operas have begun to be performed in the language in which they were written. It should be noted that this is one of the most important achievements of Hajiyeva as a result of her great efforts and hard work process. It is known that diction and pronunciation are very important in choral performing. In opera choirs performed in the original language, the harmony and influence of the music have interpretation features much closer to the composer's idea. These features form the basis of S. Hajiyeva's style of work with the choir troupe of the opera. During her activity, the choir's performance not only has improved its professional skills, but also the problem of pronunciation is solved and the sense of ensemble in the choir is increased.

In 1999, S. Hajiyeva, who studied in the class of a well-known conductor and talented artist Yalchin Adigozalov, began her pedagogical activity at the university where she studied. Many of her students work in various educational institutions and choir collectives of the republic.

In performances prepared by S. Hajiyeva, she acts as a choirmaster and conductor and this work becomes very successful. Under S. Hajiyeva's direction, who has entered our musical history as a female conductor leading a symphony orchestra for the first time, works such as U. Hajibeyli's "Koroglu", "Arshin mal alan" (choirmaster), "Asli and Kerem", "Leyli and Majnun", "If Not That One, Let It Be This One " (conductor), M. Magomayev's opera "Shah Ismayil" (conductor), Z. Hajibeyov's "Ashig Garib" (conductor), F. Amirov's "Sevil" (choirmaster), V. Adigozalov's "Natavan" opera (choirmaster), L. Weinstein's opera "Cinderella" (choirmaster), J. Puccini's "Madame Butterfly", "Tosca”, "Manon Lescaut”, "La Bohema” opera (choirmaster), P. Maskanyi's "Village honour" (choirmaster), J. Verdi's "La Traviata" (choirmaster), "Rigoletto" (choirmaster), "Troubadour" opera (choirmaster), "Don Carlos", "Aida” (choirmaster), J. Bizet's "Carmen" (choirmaster), Rossini's "Barber of Seville" (choirmaster), R. Leoncovallo's "Pagliacci” (choirmaster), P. Tchaikovsky's opera “The Queen of Spades" (choirmaster) were staged. S. Hajiyeva tries to instil the secrets of her art in students by publishing the knowledge she has gained as a result of her stage and pedagogical activity both in the form of textbooks and methodical manuals. In different years, she published a textbook "Choral compositions of Azerbaijani composers of the twentieth century" (Hajieva, 2014), as well as articles on various topics in the scientific press.

\section{Conclusions}

As we have noted, the formation of choirmaster art is closely linked with the activities of both opera theatres and cappella groups. However, these directions are com- 
bined under a single speciality of choral conducting in educational institutions teaching the secrets of this art. Gaining experience working in an opera theatre or a appella depends on the future activity of the choirmaster. Despite this, these two fields have their own style of work. The process of preparing choirs within an opera, the preparation process of choirs taken from operas in the context of independent choral works or concert performances require a different approach. First of all, the development of events on the opera stage, acting, becoming a part of the plotline, costumes, decorations and, most importantly, the inability to communicate directly with the choirmaster fundamentally distinguishes the creative activity of the opera choir troupe. These reasons place the equally complex requirements on the opera choirmaster, such as responsibility, a wide range of knowledge, working in close contact with various fields of art, having a broad knowledge of the criteria of the stage. The joint work, mutual understanding and agreement of a large creative team including a director, conductor, choirmaster, choreographer, set designer, orchestra, soloists and choir plays an important role in the formation of certain stage work. The representatives of these fields of art in addition to being professionals in their fields, should have extensive knowledge of other areas and be familiar with their work style. Otherwise, a sample of high art cannot be created.

Choir conducting is one of the most complex professions in music art. First of all, this art is distinguished by its multifunctionality. Thus, in addition to high musical knowledge, the choir conductor should have pedagogical, psychological, organizational skills, as well as director and artist thinking. The main creative task of the conductor is to be able to convey the artistic result to the listener and to know the laws of the audience's psychology of music perception. In the poet-composer-conductor-choirlistener scheme, the creative responsibility of the conductor is heavier. In addition to understanding the artistic and emotional content of the work, he must instil it in the choir and convey it to the listener. For this reason, the role of the choir conductor as an artistic director is not only important but also has significance in the formation of the aesthetic taste of the listener. There are a number of differences between the choir master's work structure working with a choir collective outside the opera and the opera choirmasters. The choirmaster, who works freely with the choir, is more independent in the presentation of the work. However, the opera choirmaster working on the preparation of choral scenes within the work should take into account the requirements of the director, conductor, set designer, orchestra and simultaneously manage to present music in accordance with the compositional structure of the single work. In this regard, the opera choirmaster has a more serious responsibility.

The educational system for choral art in Azerbaijan implements training of choir performers along with choir conductors. It should be noted that this direction as a field of conducting art is taught within a speciality as a complex. Currently, this field is taught at the Baku Music Academy and the Azerbaijan National Conservatory and the student studying here is free to decide which orchestra he/she will work with in the future. However, the special features that distinguish choir conducting from the field of conductors working with other collectives require, first of all, that the specialist who wants to work in this direction has more ability to perform choral music than others. This means that a specialist working with choir collectives should first 
get acquainted with choir music and master the methods of managing this collective in advance. The role of pedagogical activity is also very important for this. Thus, the successful activity of both independent choir collectives and choir collectives working in the opera theatres in Azerbaijan gives grounds to say that choirmaster art is still carrying its development prospects. The annual choir competitions held in the country and the active participation of children's choirs in these events mean that the interest in this art is always rejuvenated. This is an indicator of future prospects in the development of choirmaster art.

\section{References}

Abdulzade, J. (2015). Tvorcheskaya Deyatel'nost' B. Vekilovoi i Sovremennoe Khorovoe Ispolnitel'stvo [Creative Activity of B. Vekilova and Contemporary Choral Performances]. Konservatoriya [Conservatory], 3, 73-78 [in Russian].

Akhundova, G. (2016). Azərbaycanin Görkəmli Dirijorlari və Xormeysterləri [Prominent Conductors and Choirmasters of Azerbaijan]. ADPU [in Azerbaijani].

Hajibeyov, U. A. (1985). Selected works. Yazichi [in Azerbaijani].

Hajiyeva, S. I. (2014). Khorovye Sochineniya Azerbaidzhanskikh Kompozitorov XX Veka [Choral Compositions of Azerbaijani Composers of the 20th Century]. RCSS NANA [in Russian].

Hasanova, S., \& Mahmudova, G. (2017). Azərbaycanda Dirijor Sənətinin İnkişafında Cavanşir Cəfərovun Rolu [The Role of Javanshir Jafarov in the Development of the Art of Azerbaijani Conducting]. Konservatoriya [Conservatory], 4, 29-33 [in Azerbaijani].

Mamedova (Farajeva), L. (2013). Yarkii Predstavitel' Muzykal'noi Kul'tury Azerbaidzhana (Lyaman Atakishieva) [A Prominent Representative of the Musical Culture of Azerbaijan (Lyaman Atakishiyeva)]. Musiqi Dünyas [World of Music], 1, 24-29 [in Russian].

Mamedova, L. M. (2010). Khorovaya Kul'tura Azerbaidzhana [Choral Culture of Azerbaijan]. Adiloglu [in Russian].

Musin, I. A. (2006). Yazyk Dirizherskogo Zhesta ]The Language of the Conductor's Gesture]. Muzyka [in Russian].

Qafarova, Z. H. (2009). Ramiz Mustafayev. Sada [in Azerbaijani].

Yerzhemsky, G. L. (1988). Psikhologiya Dirizhirovaniya [Psychology of Conducting]. Muzyka [in Russian]. 


\section{ШЛЯХИ РОЗВИТКУ ХОРМЕЙСТЕРСЬКОГО МИСТЕЦТВА В АЗЕРБАЙДЖАНІ}

\section{Лейла Залієва}

дисертантка; ORCID: 0000-0001-8835-2008; e-mail: leyla_zaliyeva@mail.ru

Бакинська музична академія імені Узеїра Гаджибейлі, Баку, Азербайджан

\section{Анотація}

Стаття присвячена історії розвитку хорової музики в Азербайджані і висвітленню шляхів формування хормейстерського мистецтва. Розвиток хорового мистецтва в Азербайджані почався з формування композиторської творчості. Поява першої опери, включення класичних хорових зразків і формування колективу для її виконання розцінюється як перший крок у цій галузі. Пізніше поява професійних хорових колективів, розвиток оперного жанру, а також діяльність музичних навчальних закладів ознаменували новий етап розвитку. Це дозволило сформувати як хорові музичні жанри, так і напрями диригентського мистецтва (оперний хормейстер, який очолює хоровий колектив, хормейстер капели).

Мета дослідження - висвітлити становлення та вивчити шляхи розвитку хормейстерського мистецтва в Азербайджані, дослідити творчий шлях професійних оперних хормейстерів.

Методологія дослідження заснована на історико-теоретичних засадах, за допомогою яких розглянуто позицію хорового мистецтва в музичній культурі Азербайджану, історію становлення хормейстерського мистецтва. Теоретико-методологічну основу дослідження склали наявні в цій галузі роботи російських і азербайджанських музикознавців.

Наукова новизна дослідження пов'язана з тим, що вперше в Азербайджані комплексно висвітлено шляхи розвитку хормейстерського мистецтва.

Висновки. Залучення до дослідження азербайджанського хорового мистецтва і вивчення питання в аспекті формування диригентського і хорового мистецтва показали, що розвиток цієї галузі пов'язаний насамперед з композиторською творчістю. Створення класичних зразків хорової музики пов'язане з оперним жанром, тому мистецтво диригування та хормейстера вступило в фазу свого формування. У професійному напряму розвиток хормейстерського мистецтва відбувався паралельно і у взаємодії з диригентським мистецтвом, а також був пов'язаний з високим рівнем організації музичної освіти в країні. В Азербайджані зародилося ціле покоління професійних хормейстерів, як-от Е. Новрузов, Б. Векілова, С. Агаєва, Н. Марданов, Н. Набієв, З. Ісмаїлова. Я. Адигезалов, Г. Іманова, Л. Мамедова, Д. Джафаров, Ю. Кухмазова, С. Гаджиєва та ін. Проте, такі області хормейстерського мистецтва, як капела і оперний хормейстер, також розвивалися у своєму власному контексті.

Ключові слова: азербайджанська музична культура; диригент; хормейстер; національне оперне мистецтво; колектив 


\section{ПУТИ РАЗВИТИЯ ХОРМЕЙСТЕРСКОГО ИСКУССТВА В АЗЕРБАЙДЖАНЕ}

\section{Лейла Залиева}

диссертантка; ORCID: 0000-0001-8835-2008; e-mail: leyla_zaliyeva@mail.ru

Бакинская музыкальная академия имени Узеира Гаджибейли, Баку, Азербайджан

\section{Аннотация}

Статья посвящена истории развития хоровой музыки в Азербайджане и освещению путей формирования хормейстерского искусства. Развитие хорового искусства в Азербайджане началось с формирования композиторского творчества. Появление первой оперы, включение классических хоровых образцов и формирование коллектива для ее исполнения, расценивается как первый шаг в этой области. Позднее появление профессиональных хоровых коллективов, развитие оперного жанра, а также деятельность музыкальных учебных заведений ознаменовали новый этап развития. В результате это позволило сформировать как хоровые музыкальные жанры, так и направления дирижерского искусства (оперный хормейстер, возглавляющий хоровой коллектив, хормейстер капеллы).

Цель исследования - осветить становление и изучить пути развития хормейстерского искусства в Азербайджане, исследовать творческий путь профессиональных оперных хормейстеров.

Методология исследования основана на историко-теоретических принципах с помощью которых рассмотрена позиция хорового искусства в музыкальной культуре Азербайджана, история становления хормейстерского искусства. Теоретикометодологическую основу исследования составили существующие в этой области работы русских и азербайджанских музыковедов.

Научная новизна исследования связана с тем, что впервые в Азербайджане комплексно освещены пути развития хормейстерского искусства.

Выводы. Привлечение к исследованию азербайджанского хорового искусства и изучение вопроса в аспекте формирования дирижерского и хорового искусства показали, что развитие этой отрасли связано, в первую очередь, с композиторским творчеством. Создание классических образцов хоровой музыки связано с оперным жанром, поэтому искусство дирижирования и хормейстера вступило в фазу своего формирования. В профессиональном направлении развитие хормейстерского искусства, происходило параллельно и во взаимодействии с дирижерским искусством, а также было связано с высоким уровнем организации музыкального образования в стране.

В Азербайджане зародилось целое поколение профессиональных хормейстеров, таких как Э. Новрузов, Б. Векилова, С. Агаева, Н. Марданов, Н. Набиев, З. Исмаилова. Я. Адыгезалов, Г. Иманова, Л. Мамедова, Д. Джафаров, Ю. Кухмазова, С. Гаджиева и т.д. Тем не менее, такие области хормейстерского искусства, как капелла и оперный хормейстер также развивались в своем собственном контексте.

Ключевые слова: азербайджанская музыкальная культура; дирижер; хормейстер; национальное оперное искусство; коллектив 